\title{
Genetics of Resistance to Turcicum Leaf Blight caused by Exserohilum turcicum (Pass.) Leonard and Suggs in maize (Zea mays L.)
}

\author{
K.G. Bindhu ${ }^{1 *}$, K.T. Pandurangegowda ${ }^{1}$, H.C. Lohithaswa ${ }^{2}$, \\ R. Madhuri ${ }^{2}$ and N. Mallikarjuna ${ }^{1}$
}

\author{
${ }^{1}$ Department of Plant Pathology, ${ }^{2}$ Department of Genetics and Plant Breeding, College of \\ Agriculture, V. C. Farm, Mandya, Karnataka, India \\ *Corresponding author
}

\begin{tabular}{|l|}
\hline Ke y w o r d s \\
$\begin{array}{l}\text { Additive-dominance } \\
\text { model, Biparental } \\
\text { mating, Recurrent } \\
\text { selection, Six } \\
\text { generation mean, } \\
\text { Turcicum leaf blight. }\end{array}$ \\
\hline Article Info \\
\hline $\begin{array}{l}\text { Accepted: } \\
\text { 10 September } 2017 \\
\text { Available Online: } \\
\text { 10 November } 2017\end{array}$ \\
\hline
\end{tabular}

An investigation was undertaken to detect the genetic architecture of resistance of maize Turcicum leaf blight using six generation mean analysis in the two crosses viz., B-104 $\times$ CML-124 (C-I) and CML-124 × B-104 (C-II) at College of Agriculture, V. C. Farm, Mandya during Kharif 2014-15. The estimates of scaling tests A and D were significant in B104 $\times$ CML124, C and D in CML124 × B104 which suggested the significance of both additive and dominant gene effect in the inheritance of resistance in both the crosses. The scaling tests as well as joint scaling tests reveals the inadequacy of simple additivedominance model which justified the use of six parameter model for the detection of gene interactions. The components of means, additive and dominance were significant in cross B104 $\times$ CML124. The magnitude of dominance [h] effect was more compared to additive gene effect. Among interaction components, additive $x$ additive [i] and additive $\times$ dominance [j] interaction effects were significant in positive direction, whereas dominance $x$ dominance [1] interaction was significant in negative direction. In the cross CML124 $\mathrm{x}$ B104, the mean, additive and dominant [h] gene effects were significant but dominant genetic effect was significant in the negative direction. Among interaction components [i] was significant in negative direction, which implies that biparental mating or recurrent selection programmes can be used to bring out desirable genetic improvement.

\section{Introduction}

Maize (Zea mays L.) is one of the important cereal crops and it is third major crop in India after rice and wheat. Maize is native of Mexico and Central America by origin, (Galaniant, 1976; Pursglove, 1972 and Dowswell et al., 1996). The crop is affected by number of fungal diseases of which Turcicum leaf blight (TLB) or Northern corn leaf blight (NCLB) is one of the important diseases which affects the photosynthesis with severe reduction in grain yield to an extent of
28 to $91 \%$ (Robert, 1953). The disease is more prevalent in Andhra Pradesh, Karnataka, Bihar, Himachal Pradesh and Maharashtra. It is considered to be one of the most devastating foliar diseases in Karnataka resulting in reduction of grain yield by 28 to 91 per cent (Pandurangegowda et al., 1991 and Harlapur et al., 2000). Several disease management options have been recommended to reduce the impact of maize foliar diseases. Among these practices, planting of resistant 
cultivars can effectively reduce the rate of disease development and is widely recommended. Host plant resistance is considered as most practical, feasible and economical method of plant disease management. Breeding for resistance is a practical, cost-effective means available to manage the diseases (Fehr, 1987). So in order to breed a genotype with high level of resistance to Turcicum leaf blight the knowledge of gene action involved in the expression of resistant reaction in the material being handled, is a very important prerequisite. In this connection, an attempt has been made detect the mode of inheritance of resistance to TLB on maize using disease response of segregating lines and using generation mean analysis.

\section{Materials and Methods}

The present investigation was conducted during Kharif 2013-14 at Zonal Agricultural Research Station (ZARS), V.C. Farm, Mandya, which is considered as one of the 'hot spot' for Turcicum Leaf Blight (TLB) of maize. The experimental material consisted of two resistant inbred lines (B-61, B-104) and one susceptible (CML-124) which were obtained from the All India Co-ordinated Maize Improvement Project, New Delhi. By crossing these three inbreds during Kharif 2013, three $\mathrm{F}_{1} \mathrm{~S}$ viz., C-I (B-61 × CMl-124), C-II (B-104 × CML-124), C-III (CML-124 $\times$ B-104) were developed. These $F_{1} s$ were grown and selfed to get $F_{2}$ progenies and simultaneously backcrossed with respective parents to produce $\mathrm{BC}_{1}$ and $\mathrm{BC}_{2}$ progenies, during Rabi 2013. The six generations viz., $\mathrm{P}_{1}$, $\mathrm{P}_{2}, \mathrm{~F}_{1}, \mathrm{~F}_{2}, \mathrm{BC}_{1}$ and $\mathrm{BC}_{2}$ of each of the crosses were sown in RCBD in two replications during Kharif 2014. The parents and $\mathrm{F}_{1}$ 's were planted in single row each, $\mathrm{BC}_{1}$ and $\mathrm{BC}_{2}$ an eight rows and $F_{2}$ 's in 13 rows of $4 \mathrm{~m}$ length with spacing of $75 \times 20 \mathrm{~cm}$ respectively. The artificial inoculation conditions for disease development were created as described earlier. Per cent disease severity scoring was done at $60^{\text {th }}$ and $80^{\text {th }}$ day by visualizing the diseased leaf area using standard scale consisting of five broad categories, designated by $0-100$ per cent scale (James, 1971). Observations were recorded on all the 20 plants of $\mathrm{P}_{1}, \mathrm{P}_{2}$ and $\mathrm{F}_{1}$, 250 plants in $\mathrm{F}_{2}$ and 150 plants in $\mathrm{BC}_{1}$ and $\mathrm{BC}_{2}$ of all the three crosses. The pattern of inheritance was assessed by Mather's scaling test (1945), Cavalli's Joint scaling test (1952) and six parameter model.

\section{Results and Discussion}

The mean values along with standard error and variances of six generations $\left(\mathrm{P}_{1}, \mathrm{P}_{2}, \mathrm{~F}_{1}\right.$, $\mathrm{F}_{2}, \mathrm{BC}_{1}$ and $\mathrm{BC}_{2}$ ) of the maize in respect of Turcicum leaf blight are tabulated in (Table 1) and briefly presented below. Wide range of disease severity score was observed among non-segregating populations and the disease severity score was maximum (25.75) in the parent CML124 compared to other parents B61 (20.12) and B104 (12.13), while the $F_{1} S$ recorded intermediate Turcicum leaf blight score compared to its parents. Among segregating generations, the disease score of $\mathrm{BC}_{1}$ population of all the three crosses $\mathrm{B} 104 \times$ $($ B104 × CML124), B61 × (B61 × CML124), CML124 $\times($ CML124 × B104) $(24.88,20.1$, 24.13 respectively) was maximum compared to either $\mathrm{BC}_{2}(21.71,19.68,22.8$ respectively) or $\mathrm{F}_{2}(19.97,19.07,28.22$ respectively) populations.

To test the adequacy of additive-dominance model A, B, C and D scaling tests were applied. The mean and variance of six generations viz., $\mathrm{P}_{1}, \mathrm{P}_{2}, \mathrm{~F}_{1}, \mathrm{~F}_{2}, \mathrm{BC}_{1}$ and $\mathrm{BC}_{2}$ of the crosses $\mathrm{C}$-I, $\mathrm{C}$-II and $\mathrm{C}$-III in respect of Turcicum leaf blight disease score were subjected to scaling tests as per the method of Mather (1949). The results of scaling tests A, $\mathrm{B}, \mathrm{C}$ and $\mathrm{D}$ in respect of disease score of three 
crosses are presented in (Table 2). The scaling tests ' $A$ ' and ' $D$ ' were significant in the cross B104 × CML124, whereas tests ' $C$ ' and ' $D$ ' were significant in the cross CML124 $\times$ B104, indicating the inadequacy of additivedominance model, which was further confirmed by significance of additive and dominance components in joint scaling test suggested the importance of both additive and dominance gene effects in the inheritance of resistance in both the crosses. This clearly indicated presence of digenic or still higher order epistasis in the inheritance of this trait. But in the cross B61 $\times$ CML124 all four scaling tests were non-significant indicating the adequacy of additive-dominance model which is sufficient to explain the inheritance of quantitative traits in the respective cross. The significance of ' $A$ ' and ' $B$ ' scales indicated the presence of all the three types of non-allelic interactions viz., additive $\times$ additive[ํㅣ, additive $\times$ dominance [j] and dominance $x$ dominance [i] significance of interaction effects in cross B104 × CML124 and dominance $\times$ dominance [i] interaction effect in the cross CML124 $\times$ B104 was noticed in controlling the resistance to turcicum leaf blight. The significance of any one of the scaling tests indicated inadequacy of simple additive-dominance model which were further confirmed by significance of chisquare statistic indicating the role of epistasis.

Table.1 Estimates of means of generations with their standard error, variance and variance of mean for response to turcicum leaf blight

\begin{tabular}{|c|c|c|c|c|}
\hline \multirow{2}{*}{\multicolumn{2}{|c|}{ Parents/generations }} & \multicolumn{3}{|c|}{ Turcicum leaf blight } \\
\hline & & \multirow{2}{*}{$\begin{array}{c}\text { Mean + SE } \\
25.75 \pm 3.3\end{array}$} & \multirow{2}{*}{$\begin{array}{c}\text { Variance } \\
4.83\end{array}$} & \multirow{2}{*}{$\begin{array}{c}\text { Variance of mean } \\
12.2\end{array}$} \\
\hline \multirow{3}{*}{ Parents (20) } & CML24 & & & \\
\hline & B61 & $20.12 \pm 1.7$ & 64.78 & 3.23 \\
\hline & B104 & $12.13 \pm 0.48$ & 23.33 & 1.16 \\
\hline \multirow{3}{*}{ F1s (20) } & B104 × CML124 & $19.38 \pm 1.65$ & 54.52 & 2.72 \\
\hline & B61 × CML124 & $19.250 \pm 1.33$ & 35.59 & 1.77 \\
\hline & CML124 × B104 & $23.82 \pm 1.87$ & 70.66 & 3.53 \\
\hline \multirow{3}{*}{$\mathrm{F} 2 \mathrm{~s}(250)$} & B104 × CML124 & $19.97 \pm 0.42$ & 45.5 & 0.18 \\
\hline & B61 × CML124 & $19.07 \pm 0.39$ & 39.52 & 0.15 \\
\hline & CML124 × B104 & $28.22 \pm 0.67$ & 112.4 & 0.44 \\
\hline \multirow[t]{3}{*}{$\mathrm{B} 1(150)$} & B104 × (B104 × CML124 $)$ & $24.88 \pm 0.78$ & 93.4 & 0.78 \\
\hline & B61 × (B61 × CML124) & $20.1 \pm 0.53$ & 42.9 & 0.28 \\
\hline & CML124 × (CML124 × B104) & $24.13 \pm 0.79$ & 95.3 & 0.63 \\
\hline \multirow[t]{3}{*}{$\mathrm{B} 2(150)$} & CML124 × (B104 × CML124 $)$ & $21.71 \pm 0.58$ & 51.29 & 0.34 \\
\hline & CML124 × $($ B61 × CML124 $)$ & $19.68 \pm 0.7$ & 74.35 & 0.49 \\
\hline & B104 × $($ CML124 × B104 $)$ & $22.8 \pm 0.65$ & 64.4 & 0.42 \\
\hline
\end{tabular}


Table.2 Estimates of scaling tests for turcicum leaf blight scores of different generations

\begin{tabular}{|c|c|c|}
\hline CROSS & Scaling Test & Turcicum leaf blight \\
\hline \multirow{4}{*}{ C-I (B104 × CML124) } & A & $18.627 * *$ \\
\hline & $\mathrm{B}$ & -1.71 \\
\hline & $\mathrm{C}$ & 3.29 \\
\hline & $\mathrm{D}$ & $-6.63 * *$ \\
\hline \multirow{4}{*}{ C-II (B61 × CML124) } & A & 0.83 \\
\hline & B & -5.13 \\
\hline & $\mathrm{C}$ & -7.56 \\
\hline & $\mathrm{D}$ & -1.63 \\
\hline \multirow{4}{*}{ CIII (CML124 × B104) } & A & -3.07 \\
\hline & $\mathrm{B}$ & 1.7 \\
\hline & $\mathrm{C}$ & $17.621 * *$ \\
\hline & $\mathrm{D}$ & $9.49 * *$ \\
\hline
\end{tabular}

Table.3 Estimates of components of generation means and test for adequacy of additivedominance model for inheritance of Turcicum leaf blight

\begin{tabular}{|c|c|c|c|c|}
\hline Disease & Cross & $(\mathrm{m})$ & $(\mathrm{d})$ & $(\mathrm{h})$ \\
\hline \multirow{3}{*}{ Turcicum leaf blight } & B104 × CML124 & $18.7 * *$ & $2.74 * *$ & $6.74 * *$ \\
\cline { 2 - 5 } & CML124 $\times$ B104 & $21.10^{* *}$ & $-3.13 * *$ & 1.13 \\
\hline
\end{tabular}

Table.4 Estimates of components of generation means based on perfect fit solution (Joint Scaling Test) for Turcicum leaf blight

\begin{tabular}{|c|c|c|c|c|c|c|c|c|}
\hline \multirow{2}{*}{ Disease } & Cross & {$[\mathrm{fI}]$} & {$[\hat{d}]$,} & {$[\hat{h}]$,} & {$[\hat{\imath}]$,} & {$[j]$,} & {$[\hat{l}]$} & $\begin{array}{c}\text { Type of } \\
\text { epistasis }\end{array}$ \\
\hline $\begin{array}{l}\text { Turcicum } \\
\text { leaf blight }\end{array}$ & $\mathrm{B} 104 \times \mathrm{CML} 124$ & 5.66 & $-6.81^{* *}$ & $43.548^{* *}$ & $13.27^{* *}$ & $9.98^{* *}$ & $-29.83^{* *}$ & duplicate \\
\cline { 2 - 9 } & $\mathrm{CML124 \times \textrm {B } 1 0 4}$ & $42.80^{* *}$ & $3.68^{*}$ & $-39.3^{* *}$ & $-18.9^{* *}$ & -2.38 & $20.35^{* *}$ & duplicate \\
\hline
\end{tabular}


Plate.1 B104 × CML124 cross showing resistance to Turcicum leaf blight

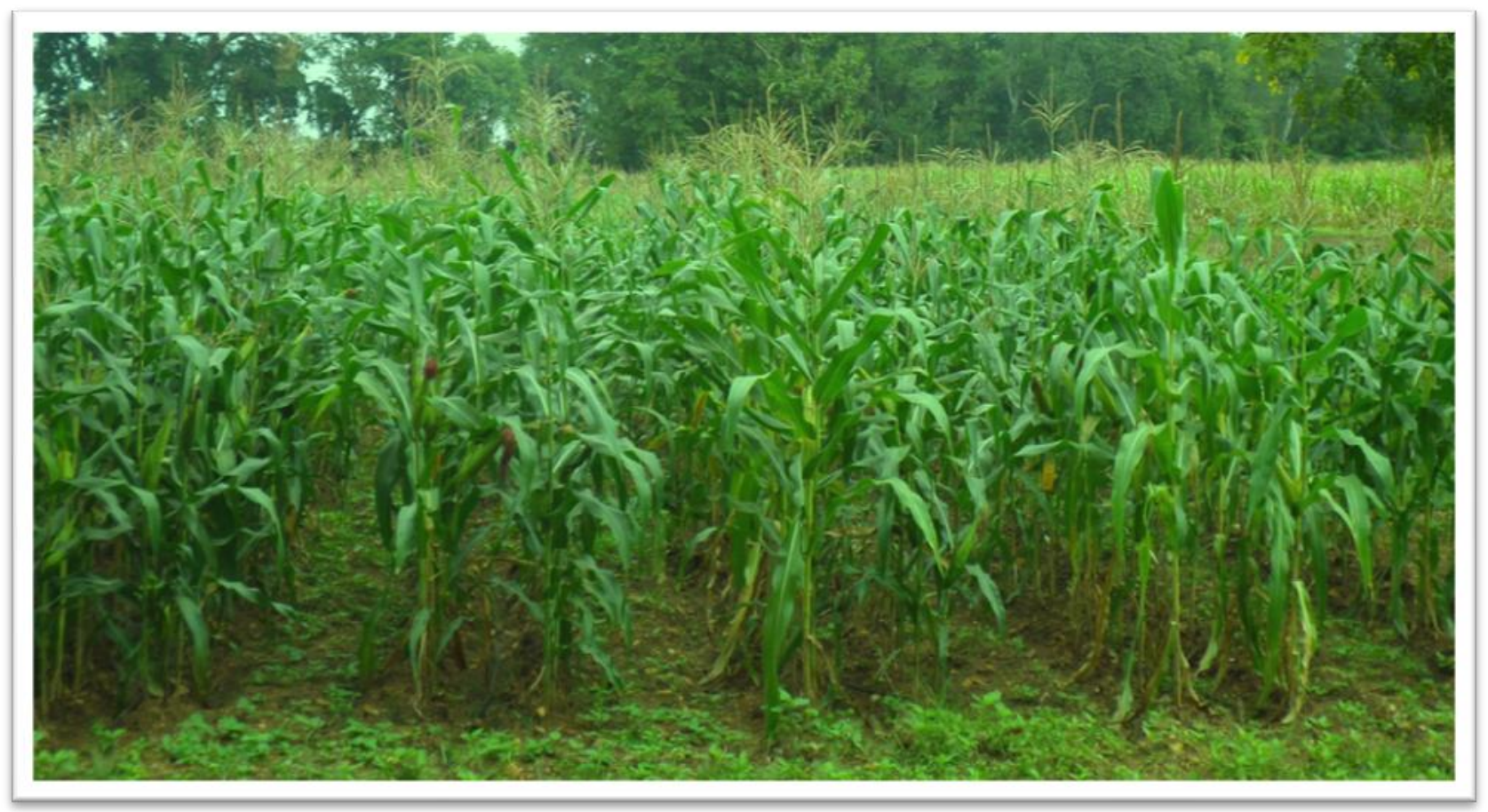

After ascertaining the failure of additivedominance model in explaining the inheritance of various quantitative characters, the perfect fit six-parameter estimates of digenic interaction model were estimated following the methods of Jinks and Jones (1958) and Mather and Jinks (1971). The six generations of the crosses viz., B104 $\times$ CML124 and CML124 $\times$ B104 were used to

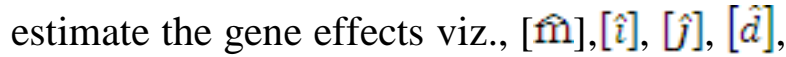
$\left[h^{\wedge}\right]$ and $[\hat{\imath}]$ for Turcicum leaf blight. The gene effects estimated by using perfect fit model in respect of disease score are tabulated in (Table 3 and 4). It is evident from six parameter model that in the cross B104 $\times$ CML124, the components mean, additive and dominance were significant. The magnitude of dominance effect was more compared to additive gene effect. Opposite signs of $\left[h^{\wedge}\right]$ and [i] components indicated the presence of duplicate gene interaction in the genetic control of Turcicum leaf blight in the crosses B104 $\times$ CML124, and CML124 $\times$ B104 which implied that biparental mating or recurrent selection programmes can be used to bring out desirable genetic improvement. Cognated results were obtained by Hettiarachchi et al., (2009), they reported the importance of additive, additive $\times$ additive, additive $x$ dominance and dominance $x$ dominance genetic effects which were well explained in the three crosses viz., CM139 $\times$ NAI147, CM139 $\times$ SKV18, CM139 $\times$ SKV21.

The scaling tests as well as joint scaling tests revealed inadequacy of simple additivedominance model which justified the use of six parameter model for the detection of gene interactions. Duplicate epistasis indicated that population improvement programmes need to be utilized for substantial genetic improvement.

\section{References}

Bagge, M. and Lubberstedt, T., 2008, Functional markers in wheat: technical 
and economic aspects. Mol. Breeding 22:319-328.

Cavalli, L. L., 1952, An analysis of linkage in quantitative inheritance. In: Quantitative Inheritance, Ed. E. C. Reeve and C. M. Waddington, pp135-144, HMSO, London.

Dowswell, C. R., Paliwal, R. L. and Cantrell, R. P., 1996, Maize in the third world, pp1-37. West view press.

Fehr, W. R., 1987, Principles of Cultivar Development. PB: Macmillan. New York. USA.

Galaninat, F., 1976. Cereal crops. Macmillan publishers company, London.

Harlapur, S.I., Wali, M.C., Anahosur, K.H. and Muralikrishna, S., 2000, A report on survey and surveillance of maize diseases in northern Karnataka. Karnataka J. Agric. Sci, 13: 750-751.

Hettiarachchi, K., Prasanna, B. M., Rajan, A., Singh, O. N., Gowda, K. T. P., Pant, S. K. and Kumar, S., 2009, Generation mean analysis of Turcicum leaf blight resistance in maize. Indian J. Genet., 69: 102-108.

James, W. C., 1971. An illustrated series of assessment keys for plant diseases, their preparation and usage. Canadian Plant Dis. Surv., 51 : 39-65.

Jinks, J. L. and Jones, R. M., 1958, Estimation of components of heterosis. Genetics, 43: 223-234.

Leonard K. J. and Suggs E. G., 1974, Setosphaeria prolata is the ascigenous state of Exserohilum prolata. Mycologia, 66: 181-297.

Lutrell, E. S., 1958, The perfect stage of Helminthosporium turcicum. Phytopathology., 48: 281-287.

Mather, K. and Jinks, J. L., 1971, Biometrical genetics. PB: Chapman and Hall, London.

Pandurangegowda, K. T., 1991, Host resistance, loss assessment and management of Exserohilum turcicum (Pass) Leonard and Suggs. leaf blight of maize. Ph.D. Thesis, Univ. Mysore.

Purslgove, G. M., 1972, Monocotyledonous crops. Third edition.Chapmam and Hall, London.

Robert, A. L., 1953. Some of the leaf blights of corn. Year Book of Agriculture, pp 380-385, United States Department of Agriculture, North Carolina.

\section{How to cite this article:}

Bindhu, K.G., K.T. Pandurangegowda, H.C. Lohithaswa, R. Madhuri and Mallikarjuna, N. 2017. Genetics of Resistance to Turcicum Leaf Blight caused by Exserohilum turcicum (Pass.) Leonard and Suggs in Maize (Zea mays L.). Int.J.Curr.Microbiol.App.Sci. 6(11): 964-969. doi: https://doi.org/10.20546/ijcmas.2017.611.113 